\title{
Nematicidal potential of Streptomyces antibioticus strain M7 against Meloidogyne incognita
}

\author{
Manish Sharma', Shivam Jasrotia², Puja Ohri ${ }^{2}$ and Rajesh Kumari Manhas ${ }^{*}$
}

\begin{abstract}
Meloidogyne spp. are microscopic, obligatory endoparasites with worldwide distribution which cause severe damage to agricultural crops. The present study revealed the nematicidal activity of Streptomyces antibioticus strain M7 against Meloidogyne incognita. The culture supernatant of the isolate caused 100\% J2 mortality after $24 \mathrm{~h}$ and inhibited egg hatching (only $3 \%$ ). In addition, the nematicidal activity of actinomycins $V_{1} X_{2}$ and D purified from strain M7 was also checked. In vitro studies displayed 97.0-99.0\% juvenile mortality and 28.0-44.0\% egg hatching after $168 \mathrm{~h}$ at $240 \mathrm{\mu g} /$ $\mathrm{ml}$ of actinomycin, with $\mathrm{LD}_{50}$ (lethal dose) values of $28-120 \mu \mathrm{g} / \mathrm{ml}$. In vivo study further validated the nematicidal activity of strain $\mathrm{M7}$, where nematode infested tomato plants treated with culture supernatant/cells/solvent extract showed reduction in root galls and egg masses per plant by $50.0-62.06 \%$ and $53.48-76.74 \%$, respectively, and significantly enhanced the shoot length (54.67-76.39\%), root length (36.45-64.88\%), shoot fresh weight (111-171.77\%), root fresh weight (120-163.33\%), shoot dry weight (54.45-145.45\%), and root dry weight (100-133.3\%) over the nematode infested plants treated with water. Furthermore, tomato plants treated with cells/culture supernatant/extract of strain M7 without nematode infestation also showed significant increase in various plant growth parameters. Thus, the outcome of the study revealed the potential of S. antibioticus strain M7 and actinomycins produced from it to be developed as safe nematicidal agents to control the root knot nematodes, and to increase the crop yield.
\end{abstract}

Keywords: Meloidogyne incognita, Streptomyces antibioticus strain M7, Nematicidal, Actinomycins

\section{Introduction}

Plant-parasitic nematodes, Meloidogyne spp., are microscopic, obligatory endoparasites that take their nourishment from plant roots (Ruanpanun et al. 2010). They cause severe damage to plants by root gall formation and root dysfunction leading to significant yield losses of agricultural crops (Caillaud et al. 2008). These plantparasitic nematodes have surface coat and egg shells which are considered as the major targets for biocontrol strategies (Bird and McClure 1976; Wharton 1980). The surface coat of nematodes, being the outermost layer of the cuticle, is composed mainly of proteins, chitin and lipids. Also, the nematode egg shell is composed of three

\footnotetext{
*Correspondence: rkmanhas@rediffmail.com

${ }^{1}$ Department of Microbiology, Guru Nanak Dev University, Amritsar,

Punjab, India

Full list of author information is available at the end of the article
}

layers, the outer most vitelline layer (protein), the middle chitinous layer and the inner lipid layer (Khan et al. 2004; Curtis 2008). In order to suppress M. incognita, the life cycle of the nematode is interrupted by volatile compounds which may be toxic to nematodes directly or they indirectly suppress nematode population by modifying the rhizosphere environment (Mishra et al. 1987). Chemical nematicides have been used to protect the plants from their infection but since these are highly toxic, expensive and become risk factor for the environment and human health, studies have been conducted to replace these chemical nematicides with naturally available biological agents (Jayakumar et al. 2005). A variety of rhizospheric microorganisms have been reported, characterized and evaluated for their biocontrol and plant growth promoting activities (El-Tarabily and Sivasithamparam 2006). Among microorganisms, actinobacteria, high G+C Gram-positive bacteria, are found to be a rich 
source of novel, and chemically diverse bioactive secondary metabolites with potential applications in agricultural field. Streptomyces spp. form the major group of actinobacteria which produce nematicidal metabolites against plant-parasitic nematodes (Dicklow et al. 1993; Samac and Kinkel 2001). Streptomyces avermitilis, a soil bacterium produces a mixture of avermectin B1a $(>80 \%)$ and avermectin B1b (<20\%). This bioactive compound, used under the name of Avicta and Agri-Mec, showed nematicidal activity against Meloidogyne spp. (M. incognita, $M$. arenaria and M. javenica) (Burg et al. 1979). Similarly, many researchers have documented the nematicidal potential of crude extracts and purified compounds from Streptomyces spp. against plant parasitic nematodes (Park et al. 2002; Yang et al. 2013; Jang et al. 2015; Kaur et al. 2016). Keeping in mind the increasing trend towards the use of microbial sources as biocontrol agents in agriculture sector, in the present study Streptomyces antibioticus strain M7 exhibiting antibacterial activity against drug resistant bacteria (Sharma and Manhas 2019) was evaluated for nematicidal potential against $M$. incognita.

\section{Materials and methods}

\section{Streptomyces antibioticus strain M7}

Streptomyces antibioticus strain M7 (MTCC 12926; GenBank accession no. KY548390) was isolated from rhizospheric soil of Stevia rebudiana (Sharma and Manhas 2019), maintained on starch casein nitrate agar slants at $4-8{ }^{\circ} \mathrm{C}$ in refrigerator and preserved the spores in $20 \%$ (v/v) glycerol suspension at $-20^{\circ} \mathrm{C}$.

\section{Nematode culture}

The roots of tomato plant (Solanum lycopersicum) were used to recover the pure culture of Meloidogyne incognita. For in vitro assays, nematode egg masses were taken out from infected tomato roots which were surface sterilized with $1.5 \%$ of sodium hypochlorite $(\mathrm{NaClO})$ solution with subsequent washing with distilled water (Hussey and Barker 1973). Surface sterilized eggs were used for egg hatching inhibition assay, and Baermann funnel method was used to extract second-stage juveniles (J2s) from egg masses by incubating egg masses in distilled water at $25^{\circ} \mathrm{C}$ for $72-120 \mathrm{~h}$ (Siddiqui and Alam 1990).

\section{Production of actinomycins}

To obtain actinomycins, fermentation was carried out for 4 days using starch casein nitrate $(\mathrm{SCN})$ broth at $28^{\circ} \mathrm{C}$ at $180 \mathrm{rpm}$. The culture broth was collected and centrifuged at $12,000 \mathrm{rpm}$ for $10 \mathrm{~min}$ at $4{ }^{\circ} \mathrm{C}$ using REMI $\mathrm{C}$-24PLUS centrifuge. The supernatant was used for screening nematicidal activity against $M$. incognita. For the recovery of nematicidal metabolites, the supernatant was adjusted to $\mathrm{pH} 5.0$ using $\mathrm{HCl}(1 \mathrm{~N})$ and extraction was done using ethyl acetate. The organic phase was separated from aqueous phase and concentrated to complete dryness under vacuum using rotary evaporator. The orange colored ethyl acetate (EtOAc) extract was subjected to silica gel chromatography, size exclusion chromatography and semi-preparative high performance liquid chromatography (HPLC) to purify the active compounds. The purified compounds were characterized as actinomycins $\mathrm{V}, \mathrm{X}_{2}$ and $\mathrm{D}$ using various spectroscopic techniques (Sharma and Manhas 2019).

\section{In vitro nematicidal activity}

To check the nematicidal efficacy of S. antibioticus strain M7, EtOAc extract and actinomycins $\left(\mathrm{V}, \mathrm{X}_{2}\right.$ and $\left.\mathrm{D}\right)$ were dissolved in autoclaved water and used at different concentrations $(30,60,120$, and $240 \mu \mathrm{g} / \mathrm{ml}$ ) against $\mathrm{J} 2 \mathrm{~s}$ and egg masses of $M$. incognita to determine the juvenile mortality and egg hatching inhibition, respectively and all experiments were verified by repeating three times.

\section{Juvenile mortality}

To check the juvenile mortality rate, the nematode culture $(200 \mathrm{~J} 2 \mathrm{~s} / 50 \mu \mathrm{l})$ suspension was added to $35 \mathrm{~mm}$ Petri plate and treated with $2 \mathrm{ml}$ of test samples viz. distilled water (negative control)/culture supernatant/EtOAc extract/actinomycins. The plates were incubated at $25^{\circ} \mathrm{C}$ for 7 days with daily examination of dead juveniles. Light microscopy was used to count the live and dead juveniles on the basis of immobility and malformation characteristics when probed with a fine needle. The juvenile mortality rate was calculated using the formula i.e. (Sun et al. 2006)

$$
\text { Mortality }(\%)=100 \times \text { dead juveniles/total juveniles. }
$$

\section{Egg hatching inhibition}

The egg masses $(200$ eggs $/ 50 \mu \mathrm{l})$ obtained from the infected tomato plants were treated with test samples (culture supernatant/EtOAc extract/actinomycins), and water was used as negative control. The Petri plates were incubated at $25 \pm 3.0{ }^{\circ} \mathrm{C}$ for $168 \mathrm{~h}$ and daily examined to calculate the egg hatch rate using formula (Sun et al. 2006):

$$
\begin{aligned}
\operatorname{Egg} \text { hatching }(\%)= & 100 \times \text { juveniles } \\
& /(\text { egg masses }+ \text { juveniles }) .
\end{aligned}
$$

\section{In vivo potential of S. antibioticus strain $\mathrm{M7}$ against $M$. incognita}

In vivo experiments were performed to study the efficacy of culture supernatant (CS), cells (CC) and EtOAc extract (SE) of S. antibioticus strain M7 under greenhouse conditions in the month of March, 2017 at $28 \pm 2.0^{\circ} \mathrm{C}$. For 
tomato seedlings, seeds susceptible to $M$. incognita (N) (Solanum lycopersicum Mill. variety Pusa Ruby) were sown in sterile soil at $28 \pm 2.0^{\circ} \mathrm{C}$ for 2 weeks and after true leaf stage, plants were transplanted singly into pots of $8 \mathrm{~cm}$ diameter containing $100 \mathrm{~g}$ sterile soil. After 2 days, plants were given different treatments and divided into 8 groups; Group 1: $10 \mathrm{ml}$ of nematode culture (100 J2s/ml of $M$. incognita), Group 2: $10 \mathrm{ml}$ of nematode culture (100 J2s/ml of M. incognita) and $10 \mathrm{ml}$ of culture supernatant obtained from 4th day old fermentation broth of S. antibioticus strain M7, Group 3: $10 \mathrm{ml}$ of nematode culture $(100 \mathrm{~J} 2 \mathrm{~s} / \mathrm{ml}$ of $M$. incognita) and $10 \mathrm{ml}$ of culture cell suspension $\left(1 \pm 10^{6}\right.$ cells $\left./ \mathrm{ml}\right)$ of $S$. antibioticus strain M7, Group 4: $10 \mathrm{ml}$ of nematode culture (100 J2s/ml of $M$. incognita) and $10 \mathrm{ml}$ of EtOAc extract $(250 \mu \mathrm{g} / \mathrm{ml})$ of S. antibioticus strain M7, Group 5: water (Negative control), Group 6: $10 \mathrm{ml}$ of culture supernatant obtained from 4th day old fermentation broth of S. antibioticus strain M7, Group 7: $10 \mathrm{ml}$ of culture cell suspension $\left(1 \pm 10^{6}\right.$ cells $\left./ \mathrm{ml}\right)$ of $S$. antibioticus strain M7, and Group 8: $10 \mathrm{ml}$ of EtOAc extract $(250 \mu \mathrm{g} / \mathrm{ml})$ of $S$. antibioticus strain $\mathrm{M} 7$. Each treatment was replicated five times and the pots were kept in greenhouse $\left(28 \pm 2.0^{\circ} \mathrm{C}\right)$ and watered daily. After 90 days, plants were uprooted carefully followed by washing with running tap water to remove the adhered soil.

\section{Statistical analysis}

The data was recorded as shoot and root lengths, root galls per root, number of egg masses per plant root (in $\mathrm{cm}$ ), fresh and dry weights of root and shoot, and statistical analysis was performed using Minitab (version 4.0) for one way analysis of variance (ANOVA) and Tukey's post hoc test was done using ASSISTAT (7.7 beta).

\section{Results}

Streptomyces antibioticus strain M7 demonstrated strong nematicidal activity against $M$. incognita (root-knot nematode). Culture supernatant (CS) and EtOAc extract (SE) of S. antibioticus caused significant J2s mortality and decreased egg hatching in M. incognita (Figs. 1a, 2a). At $24 \mathrm{~h}$ of incubation, $50.0 \%$ egg hatching was observed in control, whereas in case eggs treated with culture supernatant and EtOAc extract only $3 \%$ and $0.33 \%$ hatching was observed, respectively. Over the period of $168 \mathrm{~h}$, the egg hatching increased to $100 \%$ in control whereas
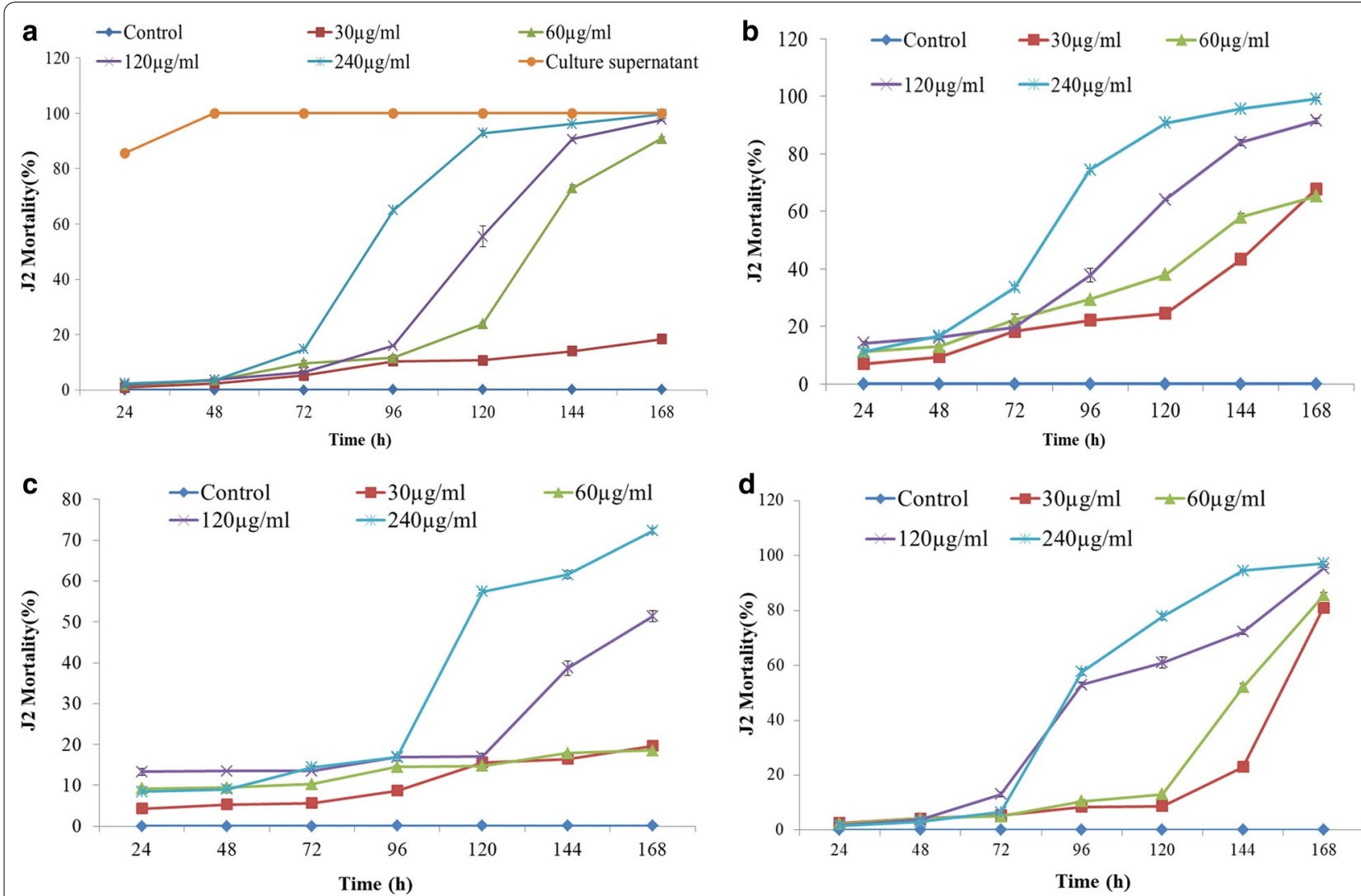

Fig. 1 Juvenile mortality in M. incognita treated with S. antibioticus strain M7 metabolites: a EtOAc extract and culture supernatant, $\mathbf{b}$ actinomycin $\mathrm{V}$ c actinomycin $\mathrm{X}_{2}$, $\mathbf{d}$ actinomycin $\mathrm{D}$ 

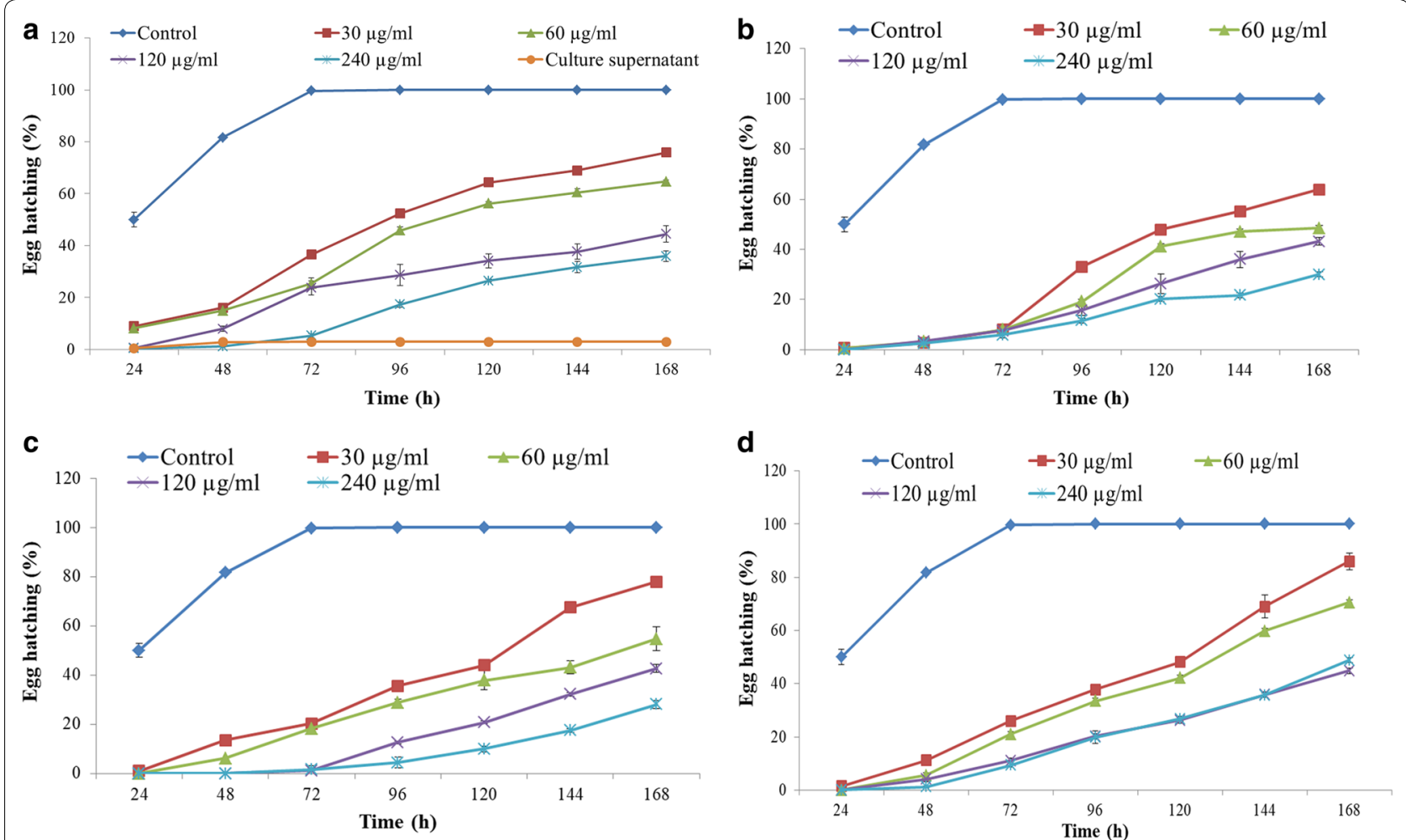

Fig. 2 Egg hatching inhibition in M. incognita treated with S. antibioticus strain M7 metabolites: a EtOAc extract and culture supernatant, $\mathbf{b}$ actinomycin $\mathrm{V}, \mathbf{c}$ actinomycin $\mathrm{X}_{2}$, $\mathbf{d}$ actinomycin D

in culture supernatant egg hatching remained 3\% and in presence of EtOAc extract, $36.0 \%$ egg hatching was observed at the highest tested concentration $(240 \mu \mathrm{g} / \mathrm{ml})$ (Fig. 2a). Similarly, culture supernatant caused 100\% J2s mortality after $48 \mathrm{~h}$ whereas EtOAc extract resulted in the maximum of $99.66 \%$ mortality after $168 \mathrm{~h}$ at a concentration of $240 \mu \mathrm{g} / \mathrm{ml}$ (Fig. 1a).

Among the actinomycins, actinomycin $\mathrm{X}_{2}$ caused 99.08\% juvenile mortality and reduced egg hatching to $28.0 \%$ at a concentration of $240 \mu \mathrm{g} / \mathrm{ml}$ after $168 \mathrm{~h}$ (Figs. 1b, 2b). On the other hand, actinomycin V which was less effective as compared to actinomycin $\mathrm{X}_{2}$, showed $72.25 \%$ juvenile mortality and $30.0 \%$ egg hatching after $168 \mathrm{~h}$ at a concentration of $240 \mu \mathrm{g} / \mathrm{ml}$ (Figs. 1c, 2c). However, when actinomycin $\mathrm{V}$ was evaluated at higher concentration $(480 \mu \mathrm{g} / \mathrm{ml})$, it showed $97 \%$ nematicidal activity after $168 \mathrm{~h}$. Actinomycin D exhibited 97.16\% juvenile mortality and $44.83 \%$ egg hatching (Figs. 1d, 2d.)

In vivo greenhouse pot experiments were carried out to further evaluate the biocontrol efficiency of strain M7. The results showed that soil drenching with culture cells, supernatant and solvent extract (EtOAc extract) in pots infested with nematode reduced the frequency of root galls and egg masses per plant by $50.0-62.06 \%$ and $53.48-76.74 \%$, respectively. Nematode infested plants treated with culture cells also significantly enhanced the shoot length (54.67-76.39\%), root length (36.45-64.88\%), shoot fresh weight (111-171.77\%), root fresh weight (120-163.33\%), shoot dry weight (54.45-145.45\%), and root dry weight (100-133.3\%) (Table 1 and Figs. 3a, 4) as compared to control plants. Furthermore, in the absence of nematode stress, soil drenching with culture cells/supernatant/EtOAc extract resulted in significant increase in plant growth parameters. The treated plants showed increase of $28.25-45.80 \%$ in the shoot length, $108.33-115.59 \%$ in root length, $125.71-190 \%$ in shoot fresh weight, $563.63-690.90 \%$ in root fresh weight, $108.33-323.80 \%$ in shoot dry weight and $400-600 \%$ in root dry weight over the control plants (Table 1 and Figs. 3b, 4).

\section{Discussion}

In agriculture, use of microorganisms for the biological control offers sustainable solution to control the harmful effects of pests (Davies 2005; Davies and Spiegel 2011) and many researchers have reported different microorganisms possessing nematicidal activity (Gu et al. 2007; Huang et al. 2010). Actinobacteria are considered the most important microbial resources which produce bioactive metabolites that can inhibit or even kill nematodes 
Table 1 Effect of S. antibioticus strain M7 on various growth traits of tomato seedlings infested with $M$. incognita

\begin{tabular}{|c|c|c|c|c|c|c|c|c|}
\hline Treatment & $\begin{array}{l}\text { Shoot length } \\
(\mathrm{cm})\end{array}$ & $\begin{array}{l}\text { Root length } \\
(\mathrm{cm})\end{array}$ & $\begin{array}{l}\text { Shoot fresh } \\
\text { weight }(g)\end{array}$ & $\begin{array}{l}\text { Root fresh } \\
\text { weight (g) }\end{array}$ & $\begin{array}{l}\text { Shoot dry } \\
\text { weight (g) }\end{array}$ & $\begin{array}{l}\text { Root dry } \\
\text { weight (g) }\end{array}$ & $\begin{array}{l}\text { No. of galls/ } \\
\mathrm{cm} \text { root }\end{array}$ & $\begin{array}{l}\text { No. of egg } \\
\text { masses/cm } \\
\text { root }\end{array}$ \\
\hline C & $28.60 \pm 0.8 b c$ & $7.44 \pm 1.2 \mathrm{c}$ & $2.45 \pm 0.07 b$ & $0.11 \pm 0.00 \mathrm{~b}$ & $0.21 \pm 0.01 \mathrm{~b}$ & $0.02 \pm 0.00 d$ & - & - \\
\hline $\mathrm{CC}$ & $\begin{array}{c}39.08 \pm 2.1 \mathrm{a} \\
(36.64)^{* * *}\end{array}$ & $\begin{array}{c}15.50 \pm 2.3 \mathrm{ab} \\
(108.33)^{* * *}\end{array}$ & $\begin{array}{l}5.53 \pm 0.40 \mathrm{a} \\
(125.71)^{* * *}\end{array}$ & $\begin{array}{c}0.83 \pm 0.15 \mathrm{ab} \\
(654.54)^{* * *}\end{array}$ & $\begin{array}{c}0.65 \pm 0.08 \mathrm{ab} \\
(204.52)^{* * *}\end{array}$ & $\begin{array}{l}0.11 \pm 0.01 \mathrm{ab} \\
(450)^{* * *}\end{array}$ & - & - \\
\hline CS & $\begin{array}{c}41.70 \pm 3.0 \mathrm{a} \\
(45.80)^{* * * *}\end{array}$ & $\begin{array}{c}15.60 \pm 1.0 \mathrm{ab} \\
(109.67)^{* * *}\end{array}$ & $\begin{array}{r}6.36 \pm 1.27 \mathrm{a} \\
(159.59)^{* * * *}\end{array}$ & $\begin{array}{c}0.87 \pm 0.34 \mathrm{a} \\
(690.90)^{* * *}\end{array}$ & $\begin{array}{c}0.89 \pm 0.27 \mathrm{ab} \\
(323.80)^{* * *}\end{array}$ & $\begin{array}{l}0.14 \pm 0.03 a b c \\
(600)^{* * *}\end{array}$ & - & - \\
\hline SE & $\begin{array}{c}36.68 \pm 1.8 \mathrm{ab} \\
(28.25)^{* * *}\end{array}$ & $\begin{array}{c}16.04 \pm 1.6 \mathrm{ab} \\
(115.59)^{* * *}\end{array}$ & $\begin{array}{c}4.35 \pm 0.24 \mathrm{ab} \\
(190.00)^{* * *}\end{array}$ & $\begin{array}{c}0.73 \pm 0.10 \mathrm{ab} \\
(563.63)^{* * *}\end{array}$ & $\begin{array}{r}0.47 \pm 0.05 \mathrm{a} \\
(108.33)^{* * *}\end{array}$ & $\begin{array}{l}0.10 \pm 0.01 \mathrm{a} \\
(400)^{* * *}\end{array}$ & - & - \\
\hline M. incognita & $24.40 \pm 2.3 c$ & $10.48 \pm 0.3 b c$ & $2.09 \pm 0.44 b$ & $0.30 \pm 0.04 \mathrm{ab}$ & $0.22 \pm 0.03 a b$ & $0.03 \pm 0 \mathrm{~cd}$ & $11.6 \pm 1.2 \mathrm{a}$ & $8.6 \pm 0.5 a$ \\
\hline $\begin{array}{l}\text { M. incog- } \\
\text { nita + CC }\end{array}$ & $\begin{array}{c}42.38 \pm 1.4 \mathrm{a} \\
(73.68)^{* *}\end{array}$ & $\begin{array}{c}17.28 \pm 1.5 \mathrm{a} \\
(64.88)^{* *}\end{array}$ & $\begin{array}{c}5.24 \pm 0.34 \mathrm{a} \\
(150.71)^{* *}\end{array}$ & $\begin{array}{c}0.79 \pm 0.18 \mathrm{ab} \\
(163.33)^{* *}\end{array}$ & $\begin{array}{l}0.42 \pm 0.05 a b \\
(90.90)^{* *}\end{array}$ & $\begin{array}{l}0.06 \pm 0.01 \\
\text { abcd } \\
(100.00)^{* *}\end{array}$ & $\begin{array}{c}5.8 \pm 0.3 b \\
(50.00)^{*}\end{array}$ & $\begin{array}{c}4.0 \pm 1.7 b \\
(53.48)^{*}\end{array}$ \\
\hline $\begin{array}{l}\text { M. incog- } \\
\text { nita + CS }\end{array}$ & $\begin{array}{c}43.04 \pm 2.5 \mathrm{a} \\
(76.39)^{* * *}\end{array}$ & $\begin{array}{l}14.30 \pm 1.0 \mathrm{ab} \\
(36.45)^{* *}\end{array}$ & $\begin{array}{c}5.68 \pm 0.44 a \\
(171.77)^{* *}\end{array}$ & $\begin{array}{c}0.66 \pm 0.08 \mathrm{ab} \\
(120.00)^{* *}\end{array}$ & $\begin{array}{l}0.54 \pm 0.04 a b \\
\quad(145.45)^{* *}\end{array}$ & $\begin{array}{l}0.07 \pm 0.01 \\
\text { abcd } \\
(133.33)^{* *}\end{array}$ & $\begin{array}{c}4.6 \pm 1.0 \mathrm{~b} \\
(62.06)^{*}\end{array}$ & $\begin{array}{c}2.0 \pm 0.8 \mathrm{~b} \\
(76.74)^{*}\end{array}$ \\
\hline $\begin{array}{l}\text { M. incog- } \\
\text { nita+SE }\end{array}$ & $\begin{array}{l}37.74 \pm 2.7 \mathrm{ab} \\
(54.67)^{* *}\end{array}$ & $\begin{array}{l}16.58 \pm 1.1 \mathrm{ab} \\
(58.20)^{* *}\end{array}$ & $\begin{array}{l}4.41 \pm 0.52 \mathrm{ab} \\
(111.00)^{* *}\end{array}$ & $\begin{array}{c}0.72 \pm 0.08 \mathrm{ab} \\
(140.00)^{* *}\end{array}$ & $\begin{array}{l}0.34 \pm 0.03 b \\
(54.54)^{* *}\end{array}$ & $\begin{array}{l}0.06 \pm 0.01 \mathrm{bcd} \\
(100.00)^{* *}\end{array}$ & $\begin{array}{c}4.4 \pm 0.5 b \\
(60.34)^{*}\end{array}$ & $\begin{array}{c}3.6 \pm 0.5 b \\
(58.14)^{*}\end{array}$ \\
\hline
\end{tabular}

Mean \pm SE followed by different letters with in a column are significantly different. Tukey's test $\mathrm{P}<0.05$

C water, CC culture cells, CS culture supernatant, SE EtOAc extract

* Values indicate percentage reduction over nematode infested plants

** Values indicate percentage increase over nematode infested plants

*** All other bracketed values indicate percentage increase over control plants

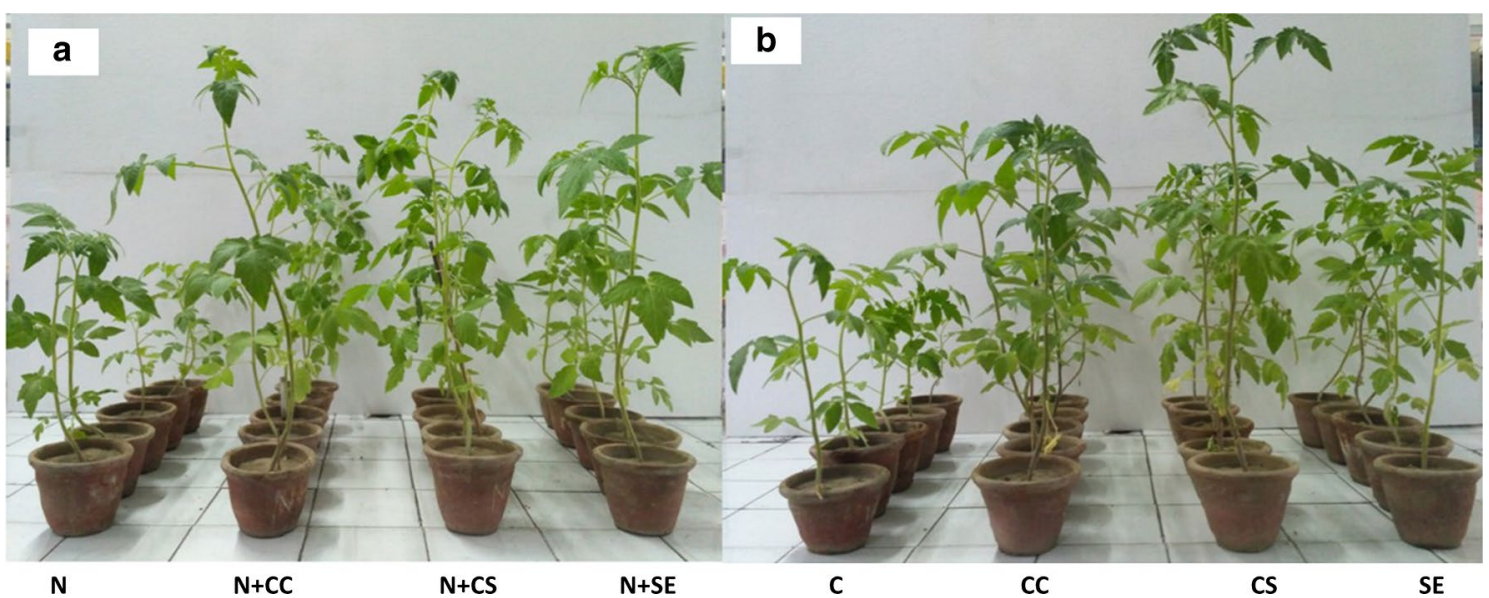

Fig. 3 In vivo protective effect of S. antibioticus strain M7 and its metabolites on shoot growth of Solanum lycopersicum plants: a infested with M. incognita and b without nematode infestation: C (water), N (nematode), CC (culture cells), CS (culture supernatant), and SE (EtOAC extract)

(Wang et al. 2010; Begum et al. 2011; Zeng et al. 2013). Streptomyces spp. are the major group of actinobacteria which show activity against plant parasitic nematodes by producing extracellular enzymes and other toxic compounds. The secondary metabolites from streptomycetes have got growing interest for the development of an ecofriendly and safe integrated crop management.

The culture broth of $S$. avermitilis Manp isolate induced $89.54 \% \mathrm{~J} 2$ mortality and reduced egg hatching to
15.73\% after 72 h (Jayakumar 2009). In 2016, Kaur et al. demonstrated 90\% J2 mortality and 1\% egg hatching after $72 \mathrm{~h}$ treatment with culture supernatant of $S$. hydrogenans strain DH16. In the present study, culture supernatant of S. antibioticus strain M7 was found to be more effective, showing 100\% juvenile mortality and 3\% egg hatching after $24 \mathrm{~h}$ and $144 \mathrm{~h}$ of incubation, respectively. The EtOAc extract of strain M7 showed 92.83\% juvenile mortality and egg hatching of $17.33 \%$ at concentration of 


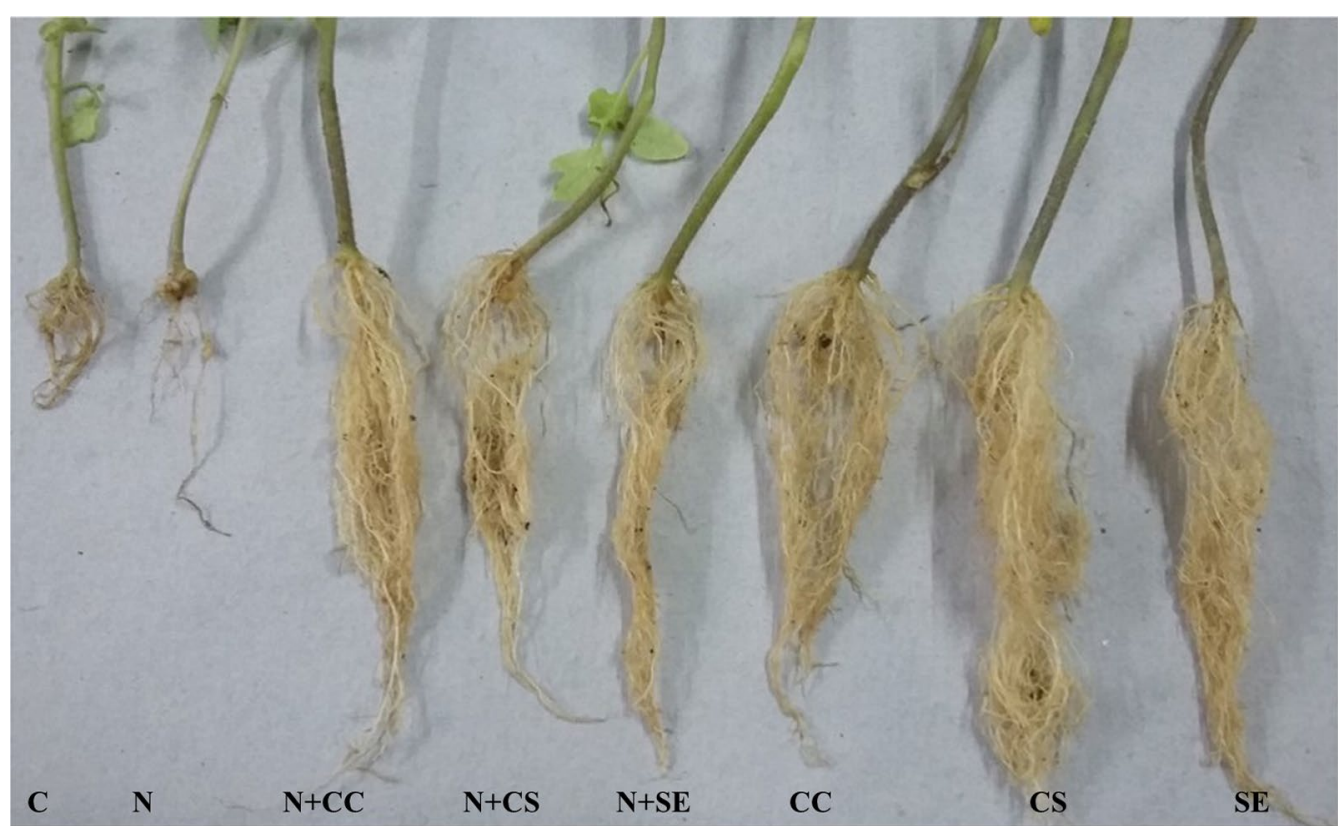

Fig. 4 In vivo protective effect of S. antibioticus strain M7 and its metabolites on root growth of Solanum lycopersicum plants infested with M. incognita; C (water), N (Nematode) CC (cells of strain M7), CS (culture supernatant) and SE (EtOAc extract)

$240 \mu \mathrm{g} / \mathrm{ml}$ after $96 \mathrm{~h}$. Jang et al. (2015) showed 83.5\% J2 mortality in solvent extract of Streptomyces netropsis at concentration of $1000 \mu \mathrm{g} / \mathrm{ml}$ after $72 \mathrm{~h}$.

In the present study, among three actinomycins produced by Streptomyces antibioticus strain M7, actinomycin $\mathrm{X}_{2}$ was more effective, showing $99.08 \%$ juvenile mortality with $\mathrm{LD}_{50}$ of $28.36 \mu \mathrm{g} / \mathrm{ml}$ after $144 \mathrm{~h}$, whereas actinomycin D and V showed juvenile mortality of $97.16 \%$ and $72.25 \%$ with $\mathrm{LD}_{50}$ values of $60 \mu \mathrm{g} / \mathrm{ml}$ and $130 \mu \mathrm{g} /$ $\mathrm{ml}$, respectively. Similarly, actinomycin $\mathrm{X}_{2}$ decreased egg hatching to $17.50 \%$ whereas actinomycin $\mathrm{D}$ and actinomycin $\mathrm{V}$ reduced it to $35.66 \%$ and $21.66 \%$, respectively after $144 \mathrm{~h}$ at concentration of $240 \mu \mathrm{g} / \mathrm{ml}$. Ruanpanun et al. (2011) reported a Streptomyces sp. CMU-M021 producing two antifungal compounds i.e. fervenuline and isocoumarin exhibiting nematicidal activity. Out of the two compounds, isocoumarin showed weak effect on $\mathrm{J} 2$ mortality and no effect on egg hatching whereas fervenuline showed $100 \%$ juvenile mortality and 5\% egg hatch after incubation for $96 \mathrm{~h}$ and $160 \mathrm{~h}$, respectively at concentration of $250 \mu \mathrm{g} / \mathrm{ml}$ which is comparable to nematicidal activity of purified compound actinomycin $\mathrm{X}_{2}$ in the present study. Kaur et al. (2016) reported a novel antifungal compound from Streptomyces hydrogenans strain DH16 possessing strong nematicidal activity, having $\mathrm{LD}_{50}$ of $50 \mu \mathrm{g} / \mathrm{ml}$ for $\mathrm{J} 2 \mathrm{~s}$ mortality, and $14 \%$ egg hatching after $72 \mathrm{~h}$ of incubation at concentration $100 \mu \mathrm{g} / \mathrm{ml}$.

The results of in vitro experiments showed that actinomycins exhibited significant nematicidal activity against $M$. incognita, and can be used as nematicides to control root-knot nematodes (RNKs). Actinomycins are one of the clinically important, chromopeptide lactone anticancer drugs which have been generally used for the treatment of Wilms' tumor and childhood rhabdomyosarcoma (Chen et al. 2012). These drugs are also in use against bacterial and fungal pathogens such as S. aureus, B. subtilis, S. faecalis, E. coli, P. aeruginosa, C. albicans, A. niger and A. flavus (Hamza et al. 2013; Kulkarnia et al. 2017). Although, these drugs were discovered in 1940 's, but their biological and medicinal relevancies are still to be explored in many research areas.

In 1979, Sawhney and Webster (1979) evaluated in vivo effect of actinomycin D against Meloidogyne incognita and observed no gall formation in treated tomato plants. In the present study, in vivo pot experiment demonstrated positive effect of treatment of plants with culture cells/supernatant/EtOAc extract (containing actinomycins) of strain $\mathrm{M} 7$ on plant growth by reducing the formation of root galls and egg masses in nematode infested tomato plants. Similarly, in the absence of nematode stress, treatment of plants improved the quality of plant, showing enhanced root and shoot lengths, and root and shoot weights as compared to control plants treated with water only. The culture supernatant was found to be more effective as compared to cells and EtOAc extract, nearly eliminated root-galling and reduced egg masses per plant. 
This study is the first report demonstrating the nematicidal potential of Streptomyces antibioticus strain M7 against $M$. incognita. The results of in vitro and in vivo studies indicate that culture cells and EtOAc extract (actinomycins) have the potential to control nematode infestations and to reduce its ill effects on crop production. Therefore, the Streptomyces strain M7 and its metabolites might be developed as safe biopesticide and effective fertilizer to control phytopathogens and promote plant growth.

\section{Abbreviations}

J2s: second-stage juveniles; SCN: starch casein nitrate; $\mathrm{LD}_{50}$ : lethal dose.

\section{Acknowledgements}

We duly acknowledge University Grant Commission, New Delhi for the financial support to accomplish this research work. One of the authors, Manish Sharma acknowledges the grant of fellowship under University with Potential for Excellence scheme of University Grants Commission (UGC-UPE), New Delhi, India.

\section{Authors' contributions \\ RKM as research supervisor of MS designed and planned the research work; analysed and interpreted experimental data and was involved in drafting as well as critical editing of the manuscript for intellectual subject matter. PO helped in the designing and execution of the work, interpretation of data and manuscript writing. MS was involved in the planning and implementa- tion of experimental work; analysis and interpretation of the data; writing of manuscript following the instructions of the research guide. SJ was involved in the execution of the work, and analysis of the data. All authors read and approved the final manuscript.}

\section{Funding}

This work was financially supported by the University Grants Commission (UGC), New Delhi vide Letter No. (Letter No. F. No. 43-468/2014(SR) dated 24/9/15).

\section{Availability of data and materials}

All the data and materials have been provided in main manuscript.

\section{Ethics approval and consent to participate}

Not applicable.

\section{Consent for publication}

Not applicable.

\section{Competing interests}

The authors declare that they have no competing interests.

\section{Author details}

${ }^{1}$ Department of Microbiology, Guru Nanak Dev University, Amritsar, Punjab, India. ${ }^{2}$ Department of Zoology, Guru Nanak Dev University, Amritsar, Punjab, India.

Received: 16 August 2019 Accepted: 10 October 2019

Published online: 22 October 2019

\section{References}

Begum S, Perwaiz S, Siddiqui BS, Khan S, Fayyaz S, Ramzan M (2011) Chemical constituents of Cordia latifolia and their nematicidal activity. Chem Biodivers 8:850-861

Bird AF, McClure MA (1976) The tylenchid (Nematoda) egg shell: structure, composition and permeability. Parasitol 72:19-28
Burg RW, Miller BM, Baker EE, Birnbaum J, Currie SA, Hartman R, Kong YL, Monaghan RL, Olson G, Putter I, Tunac JB, Wallick H, Stapley EO, Oiwa R, Omura S (1979) Avermectins, new family of potent anthelmintic agents: producing organism and fermentation. Antimicrob Agents Chemother 15:361-367

Caillaud MC, Dubreuil G, Quentin M, Perfus-Barbeoch L, Lecomte P, de Almeida Engler J, Abad P, Rosso MN, Favery B (2008) Root-knot nematodes manipulate plant cell functions during a compatible interaction. J Plant Physiol 165:104-113

Chen C, Song F, Wang Q, Abdel-Mageed WM, Guo H, Fu C, Hou W, Dai H, Liu X, Yang N, Xie F, Yu K, Chen R, Zhang L (2012) A marine-derived Streptomyces sp. MS449 produces high yield of actinomycin X2 and actinomycin D with potent anti-tuberculosis activity. Appl Microbiol Biotechnol 95:919-927

Curtis RH (2008) Plant-nematode interactions: environmental signals detected by the nematode's chemosensory organs control changes in the surface cuticle and behavior. Parasite 15:310-316

Davies KG (2005) Interactions between nematodes and microorganisms: bridging ecological and molecular approaches. Adv Appl Microbiol 57:53-78

Davies KG, Spiegel Y (2011) Biological control of plant parasitic nematodes: towards understanding field variation through molecular mechanisms. In: Jones J, Gheysen G, Fenoll C (eds) Exploiting genomics to understand plant-nematode interactions. Springer, New York (in press)

Dicklow MB, Acosta N, Zuckerman BM (1993) A novel Streptomyces species for controlling plant-parasitic nematodes. J Chem Ecol 19:159-173

El-Tarabily K, Sivasithamparam K (2006) Non-streptomycete actinomycetes as biocontrol agents of soil-borne fungal plant pathogens and as plant growth promoters. Soil Biol Biochem 38:1505-1520

Gu YQ, Zhou JP, Zou CS, Mo MH, Zhang KQ (2007) Evaluation and identification of potential organic nematocidal volatiles from soil bacteria. Soil Biol Biochem 39:2567-2575

Hamza AA, Ali HA, Clark BR, Murphy CD, Elobaid EA (2013) Isolation and characterization of actinomycin D producing Streptomyces spp. From Sudanese soil. Afr J Biotechnol 12:2624-2632

Huang Y, Xu CK, Ma L, Zhang KQ, Duan CQ, MingHe M (2010) Characterisation of volatiles produced from Bacillus megaterium YFM3.25 and their nematicidal activity against Meloidogyne incognita. Eur J Plant Pathol 126:417-422

Hussey RS, Barker KR (1973) A comparison of methods of collecting inocula of Meloidogyne spp., including a new technique. Plant Dis Rep $57: 1025-1028$

Jang JY, Choi YH, Joo YJ, Kim H, Choi GJ, Jang KS, Kim CJ, Cha B, Park HW, Kim JC (2015) Characterization of Streptomyces netropsis showing a nematicidal activity against Meloidogyne incognita. Res Plant Dis 21:50-57

Jayakumar J (2009) Bio-efficacy of Streptomyces avermitilis culture filtrates against root knot nematode, Meloidogyne incognita and reniform nematodes, Rotylenchulus reniformis. Karnataka J Agric Sci 22:567-571

Jayakumar J, Rajendran G, Ramakrishnan S (2005) Screening of Streptomyces avermitilis culture filtrates in in vitro against root knot and reniform nematodes. Indian J Plant Prot 33:129-133

Kaur T, Jasrotia S, Ohri P, Manhas RK (2016) Evaluation of in vitro and in vivo nematicidal potential of a multifunctional streptomycete, Streptomyces hydrogenans strain DH16 against Meloidogyne incognita. Microbiol Res 192:247-252

Khan A, Williams KL, Nevalainen HKM (2004) Effects of Paecilomyces lilacinus protease and chitinase on the eggshell structures and hatching of Meloidogyne javenica juveniles. Biol Control 31:346-352

Kulkarnia M, Gorthia S, Banerjee G, Chattopadhyay P (2017) Production, characterization and optimization of actinomycin D from Streptomyces hydrogenans IB310, an antagonistic bacterium against phytopathogens. Biocatal Agric Biotechnol 10:69-74

Mishra SK, Keller JE, Miller JR, Heisey RM, Nair MG, Putnam AR (1987) Insecticidal and nematicidal properties of microbial metabolites. J Ind Microbiol 2:267-276

Park JO, El-Tarabily KA, Ghisalberti EL, Sivasithamparam K (2002) Pathogenesis of Streptoverticillium albireticuli on Caenorhabditis elegans and its antagonism to soil borne fungal pathogens. Lett Appl Microbiol 35:361-365

Ruanpanun P, Tangchitsomkid N, Hyde KD, Lumyong S (2010) Actinomycetes and fungi isolated from plant-parasitic nematode infested soils: 
screening of the effective biocontrol potential, indole-3-acetic acid and siderophore production. World J Microbiol Biotechnol 26:1569-1578

Ruanpanun P, Laatsch H, Tangchitsomkid N, Lumyong S (2011) Nematicidal activity of fervenulin isolated from a nematicidal actinomycete, Streptomyces sp. CMU-MH021, on Meloidogyne incognita. World J Microbiol Biotechnol 27:1373-1380

Samac DA, Kinkel LL (2001) Suppression of the root-lesion nematode (Pratylenchus penetrans) in alfalfa (Medicago sativa) by Streptomyces spp. Plant Soil 235:35-44

Sawhney R, Webster MJ (1979) The influence of some metabolic inhibitors on the response of susceptible/resistant cultivars of tomato to Meloidogyne Incognita. Nematologica 25:86-93

Sharma M, Manhas RK (2019) Purification and characterization of actinomycins from Streptomyces strain M7 active against Methicillin Resistant Staphylococcus aureus and Vancomycin Resistant Enterococcus. BMC Microbiol 19:44

Siddiqui MA, Alam MM (1990) Further studies on the use of water hyacinth in nematode control. Biol Waste 33:71-75

Sun MH, Gao L, Shi YX, Li BJ, Liu XZ (2006) Fungi and Actinomycetes associated with Meloidogyne spp. eggs and females in China and their biocontrol potential. J Invert Pathol 93:22-28
Wang XJ, Wang M, Wang JD, Jiang L, Wang JJ (2010) Isolation and identification of novel macrocyclic lactones from Streptomyces avermitilis NEAU1069 with acaricidal and nematocidal activity. J Agric Food Chem 58:2710-2714

Wharton D (1980) Nematode eggshells. Parasitology 81:447-463

Yang LY, Wang JD, Zhang J, Xue CY, Zhang H, Wang XJ, Xiang WS (2013) New nemadectin congeners with acaricidal and nematocidal activity from Streptomyces microflavus neau3 Y-3. Bioorg Med Chem Lett 23:5710-5713 Zeng Q, Huang H, Zhu J, Fang Z, Sun Q, Bao S (2013) A new nematicidal compound produced by Streptomyces albogriseolus HA10002. Ant Van Leeuwenhoek 103:1107-1111

\section{Publisher's Note}

Springer Nature remains neutral with regard to jurisdictional claims in published maps and institutional affiliations.

\section{Submit your manuscript to a SpringerOpen ${ }^{\circ}$ journal and benefit from:}

- Convenient online submission

- Rigorous peer review

- Open access: articles freely available online

- High visibility within the field

- Retaining the copyright to your article

Submit your next manuscript at $\gg$ springeropen.com 